\title{
Mothers' Knowledge and Behavior of Anemia Prevention in Children: Application of Pender's Health Promotion Model
}

\author{
Ni Kadek Dwi Anjani' ${ }^{1}$ BybaMelda Suhita ${ }^{2}$, \\ Yenny Puspitasari ${ }^{2}$ \\ ${ }^{1}$ Post graduate student of the Institute of Health \\ Sciences Strada Indonesia \\ ${ }^{2}$ Lecture of the Institute of Health Strada \\ Indonesia \\ Email: \\ nikadekdwianjani@gmail.com
}

\begin{abstract}
Prevalence of anemia in children in Indonesia is still quite high. Parents' behavior in preventing anemia in children is still lacking. Health promotion model (HPM) with a Pender's model is needed. This study was aimed to develop a model of health promotion with a Pender theory approach to maternal behavior on the prevention of childhood anemia. Quasi Experiment with Pre and Post Test design was conducted in Kubutambahan II Primary Health Care. Data was collected in 100 respondents and analyzed by Mc Nemar test. The results showed there was an effect of health promotion on mother's knowledge of anemia prevention $(\mathrm{p}=0,000)$. There was no effect of health promotion on mother's attitudes of anemia prevention $(\mathrm{p}=0.845)$. There is an effect of health promotion on the actions/ behavior of mothers regarding the prevention of anemia in children $(\mathrm{p}=0,000)$. The developing health promotion based on the HPM approach can increase knowledge and behavior about preventing anemia. Health promotion by conducting outreach to the community needs to be carried out continuously by involving all aspects such as health workers, community leaders, community health workers and families to improve community health status.
\end{abstract}

Keywords: anemia prevention. behavior, health promotion, knowledge

Copyright (C) 2020 IIK STRADA Indonesia All right reserved.

This is an open-acces article distributed under the terms of the Creative Commons Attribution-ShareAlike 4.0 International License.

\section{INTRODUCTION}

Anemia is a blood disorder that occurs because the amount of healthy hemoglobin or red blood cells in the body is less than normal. WHO data in the Worldwide Prevalence of Anemia in 2008 showed that $48.8 \%$ of the world's population suffer from anemia. The highest prevalence occurs in toddlers $47.4 \%$, pregnant women $41.8 \%$, while in school-age children is $25.4 \%$, which means 305 million school-age children worldwide suffer from anemia (WHO, 2008). In Indonesia, prevalence of 
anemia in children under five is around $30-40 \%$ while in school children $25-35 \%$ is caused by poverty, malnutrition, vitamin A deficiency and folic acid (WHO, 2008).

Prevalence of anemia is quite high in school-age children due to improper eating habits, irregular and adequate sources of nutrition needed by the body is not balanced. At this age children have a high activity and a lot of energy expended to play and learn while eating habits such as not having breakfast before leaving school, consumption of foods that contain less iron is still often done (Kisworini \& Mulatsih, 2005). Children's eating patterns are usually influenced by friends in the school environment and the environment outside the home as well as the presence of advertisements or advertisements on television (Supartini, 2004). On the other hand, parents are often not aware of and not understand about anemia, the causes and effects of anemia on children, some parents only know that anemia only occurs in adults, so preventive measures for anemia in children are not done (Syah, 2007). Increasing the ability of parents, especially mothers in preventing anemia in children with education and counseling is one of the actions that can be done. It is hoped that parents' knowledge and behavior in providing child food and children's eating patterns will be better so that food intake, especially children's iron intake will be better too (Health Department of RI, 2007).

Health promotion with the Health Promotion Model (HPM) approach presented by Nola J Pender is an effort to be able to help understand individual health behaviors and can be a guideline in providing counseling to promote healthy behavior. In the theory explained previous behavior, personal factors, the benefits of action, obstacles, self-ability, attitudes associated with activities, interpersonal and situational influences and commitment greatly affect one's behavior in achieving optimal health status (Pender, Murdaugh, \& Parsons, 2002).

A preliminary study was conducted in the Kubutambahan II Primary Health Care for 25 children, from the results of the $\mathrm{Hb}$ examination as much as $8 \%$ (2 children) had anemia. Observations were continued with 6 children in elementary schools in the local area, 3 children were found to be weak, lethargic, pale conjunctiva, sleepy and not concentrated while studying, while 3 conjunctival children were not anemic, could focus while studying and had good grades. The results of interviews with parents, most parents do not know about anemia and do not know if anemia can be experienced by children. Providing health promotion with the Health Promotion Model approach is expected to increase maternal awareness and increase information in taking anemia prevention measures.

This study aims to develop a health promotion model based on a Pender theory approach to knowledge, attitudes and behaviors of mothers about preventing anemia in children.

\section{MATERIALS AND METHODS}

This research was conducted in the Kubutambahan II Primary Health Care using quasi experiment design and pre-post design approach. The study was conducted in November-December 2019 to 100 mothers who have elementary school children aged 10-11 years. Pre and post data collection is done by using a questionnaire. Health promotion is carried out by providing counseling 3 times a week for 3 weeks and then the analysis of data is done using the Mc.Nemar Test. This study has received an Ethical Approval from the STIKes Buleleng Health Research Ethics Commission with Number: 135 /EC-KEPK-SB / X / 2019.

\section{RESULTS}

\section{Description of Place of Study}

Kubutambahan II Primary Health Care is located on Jalan Raya Singaraja-Kintamani, Tamblang Village, Kubutambahan District, Buleleng Regency. The total population of the Kubutambahan II Primary Health Care's work area in 2018 was 15,165 males and 14,961 females with an area of 41 $\mathrm{km} 2$ consisting of 8 villages

\section{Descriptive Public Data}

Characteristics of respondents can be seen in Table 1. Characteristics of respondents seen by age, education, occupation, number of children and age of the child. The results showed that some 
respondents (46\%) were 36-40 years old, 37\% had high school education, 55\% of mothers did not work, $41 \%$ had 2 children, and $59 \%$ had children aged 10 years.

Tabel 1. Distribution of characteristics respondents in Kubutambahan II Primary Health Care, 2019

\begin{tabular}{lcc} 
Characteristic Respondents & $\sum$ & $\%$ \\
\hline Age & 3 & 3 \\
20-25 years & 3 & 3 \\
26-30years & 46 & 46 \\
31-35years & 34 & 34 \\
36-40 years & 17 & 17 \\
Education & & \\
Junior High School & 16 & 16 \\
Secondary High School & 32 & 32 \\
Senior High School and above & 42 & 42 \\
Status of working & & \\
Not working & 55 & 55 \\
Private employee & 24 & 24 \\
Government employee & 3 & 3 \\
Others & 18 & 18 \\
Parity & & \\
1 & 6 & 6 \\
2 & 41 & 41 \\
$\geq 3$ & 53 & 53 \\
Children's age birth & & \\
10 years & 59 & 59 \\
11 years & 41 & 41 \\
Total & 100 & 100 \\
\hline
\end{tabular}

Source: Primary data

Table 2. Cross Tabulation between Variabel Dependen and Health Promotion in Kubutambahan II Primary Health Care, 2019

\begin{tabular}{llcc}
\hline No & \multicolumn{1}{c}{ Variabel } & $\begin{array}{c}\text { Pre } \\
\sum(\mathbf{\%})\end{array}$ & $\begin{array}{c}\text { Post } \\
\sum(\mathbf{\%})\end{array}$ \\
\hline 1 & Knowledge & & \\
& Good & $56(56 \%)$ & $64(64 \%)$ \\
& Less & $44(44 \%)$ & $36(36 \%)$ \\
2 & Attitude & & $47(47 \%)$ \\
& Positive & $45(45 \%)$ & $53(53 \%)$ \\
& Negative & $55(55 \%)$ & $70(70 \%)$ \\
3 & Behavior & & $30(30 \%)$ \\
& Good & $50(50 \%)$ & \\
& Less & $50(50 \%)$ & \\
\hline
\end{tabular}

Source: Primary data

Based on Table 2. it can be seen that most of the respondents' knowledge before joining the health promotion program is in the good category. Most of the respondents' knowledge after health 
promotion was in the good category. Most of the respondents' attitudes before joining the health promotion program were negative. Most of the respondents' attitudes after internal health promotion were negative. Half of the respondents' behavior before joining the health promotion program was in the good category. Most of the respondents' behavior before joining the health promotion program was in the good category.

Table 3. Cross Tabulation between characteristic respondents and Pre Test in Kubutambahan II Primary Health Care, 2019

\begin{tabular}{|c|c|c|c|c|c|c|c|}
\hline \multirow{3}{*}{ No } & \multirow{3}{*}{$\begin{array}{l}\text { Characteristic } \\
\text { Respondents }\end{array}$} & \multicolumn{6}{|c|}{ Pre Test } \\
\hline & & \multicolumn{2}{|c|}{ Knowledge } & \multicolumn{2}{|c|}{ Attitude } & \multicolumn{2}{|c|}{ Behavior } \\
\hline & & Good & Less & Positive & Negative & Good & Less \\
\hline \multirow[t]{5}{*}{1} & Age & & & & & & \\
\hline & $20-25$ years & 1 & 2 & 0 & 3 & 2 & 1 \\
\hline & 26-30years & 25 & 21 & 21 & 25 & 20 & 26 \\
\hline & 31-35years & 19 & 15 & 18 & 16 & 17 & 17 \\
\hline & $36-40$ years & 11 & 6 & 6 & 6 & 11 & 6 \\
\hline \multirow[t]{4}{*}{2} & Education & & & & & & \\
\hline & Junior High School & 3 & 13 & 2 & 14 & 8 & 8 \\
\hline & Secondary High School & 11 & 21 & 8 & 24 & 20 & 12 \\
\hline & Senior High School and & 42 & 10 & 35 & 17 & 22 & 30 \\
\hline \multirow[t]{5}{*}{3} & Status of working & & & & & & \\
\hline & Not working & 24 & 31 & 23 & 32 & 27 & 28 \\
\hline & Private employee & 21 & 3 & 16 & 8 & 10 & 14 \\
\hline & Government employee & 3 & 0 & 3 & 0 & 3 & 0 \\
\hline & Others & 8 & 10 & 3 & 15 & 10 & 8 \\
\hline \multirow[t]{4}{*}{4} & Parity & & & & & & \\
\hline & 1 & 5 & 1 & 3 & 3 & 3 & 3 \\
\hline & 2 & 27 & 14 & 26 & 15 & 19 & 22 \\
\hline & $\geq 3$ & 24 & 29 & 16 & 37 & 28 & 25 \\
\hline \multirow[t]{3}{*}{5} & Children's age birth & & & & & & \\
\hline & 10 years & 26 & 20 & 29 & 32 & 33 & 31 \\
\hline & 11 years & 30 & 24 & 16 & 23 & 17 & 19 \\
\hline
\end{tabular}

Source: Primary data

Table 4. Cross Tabulation between characteristic respondents and Post Test in Kubutambahan II Primary Health Care, 2019

\begin{tabular}{|c|c|c|c|c|c|c|c|}
\hline \multirow{3}{*}{ No } & \multirow{3}{*}{$\begin{array}{l}\text { Characteristic } \\
\text { Respondents }\end{array}$} & \multicolumn{6}{|c|}{ Post Test } \\
\hline & & \multicolumn{2}{|c|}{ Knowledge } & \multicolumn{2}{|c|}{ Attitude } & \multicolumn{2}{|c|}{ Behavior } \\
\hline & & Good & Less & Positive & Negative & Good & Less \\
\hline \multirow[t]{5}{*}{1} & Age & & & & & & \\
\hline & $20-25$ years & 1 & 2 & 0 & 3 & 1 & 2 \\
\hline & 26-30years & 30 & 16 & 23 & 23 & 9 & 37 \\
\hline & 31-35years & 22 & 12 & 14 & 20 & 12 & 22 \\
\hline & $36-40$ years & 11 & 6 & 10 & 7 & 8 & 9 \\
\hline \multirow[t]{4}{*}{2} & Education & & & & & & \\
\hline & Junior High School & 5 & 11 & 2 & 14 & 3 & 13 \\
\hline & Secondary High School & 14 & 18 & 16 & 16 & 11 & 21 \\
\hline & Senior High School and & 44 & 7 & 29 & 23 & 16 & 36 \\
\hline
\end{tabular}




\begin{tabular}{|c|c|c|c|c|c|c|c|}
\hline \multirow[t]{5}{*}{3} & Status of working & & & & & & \\
\hline & Not working & 29 & 26 & 21 & 34 & 14 & 41 \\
\hline & Private employee & 21 & 3 & 17 & 7 & 8 & 16 \\
\hline & Government employee & 3 & 0 & 3 & 0 & 3 & 0 \\
\hline & Others & 11 & 7 & 6 & 12 & 5 & 13 \\
\hline \multirow[t]{4}{*}{4} & Parity & & & & & & \\
\hline & 1 & 6 & 0 & 3 & 3 & 2 & 4 \\
\hline & 2 & 29 & 12 & 22 & 19 & 10 & 31 \\
\hline & $\geq 3$ & 29 & 24 & 22 & 31 & 18 & 35 \\
\hline \multirow[t]{3}{*}{5} & Children's age birth & & & & & & \\
\hline & 10 years & 39 & 20 & 30 & 29 & 36 & 23 \\
\hline & 11 years & 30 & 11 & 25 & 16 & 30 & 13 \\
\hline
\end{tabular}

Source: Primary data

Table 3. and Table 4. shows the cross tabulation between respondent characteristics and knowledge, attitude and behavior both before and after health promotion. Knowledge improvement occurred in respondents aged 26-30 years and 31-35 years, at all levels of education (junior high school, secondary high school, or senior high school), in mothers who did not work and at all parities. Increased attitudes occurred in respondents aged 20-25 years, 26-30 years and 36-40 years, respondents who have secondary high school education and respondents who have the number of children 2 . While increased behavior experienced by respondents in all age groups, all levels of education, also experienced by mothers who do not work and private employees and all parity groups.

Table 5. Application Pender's Health Promotion Model on Mother's Knowledge of Anemia Prevention in Kubutambahan II Primary Health Care, 2019

\begin{tabular}{lccccc}
\hline \multicolumn{1}{c}{ Knowledge } & $\Sigma$ & Pre & $\%$ & $\sum_{1}$ & Post \\
\hline Good & 56 & 56 & 64 & 64 \\
Less & 44 & 44 & 36 & 36 \\
Total & 100 & 100 & 100 & 100 \\
Mc Nemar $\mathrm{p}=0,000$ & & & & & \\
\hline
\end{tabular}

Source: Primary data

Based on Table 5. it was found that the majority (56\%) of knowledge before getting health promotion in the good category and the majority (64\%) of respondents' knowledge after getting health promotion in the good category. Based on the test with Mc Nemar, the result $p=0,000$ means that there is an effect of health promotion on respondents' knowledge of anemia prevention.

Table 6. Application Pender's Health Promotion Model on Mother's Attitude of Anemia Prevention in Kubutambahan II Primary Health Care, 2019

\begin{tabular}{cccccc}
\hline \multirow{2}{*}{ Attitude } & Pre & & \multicolumn{3}{c}{ Post } \\
& $\Sigma$ & & $\%$ & 47 & 47 \\
\hline Positive & 45 & 45 & 53 & 53 \\
Negative & 55 & 55 & 100 & 100 \\
Total & 100 & 100 & & \\
Mc Nemar $\mathrm{p}=0,845$ & & & & \\
\hline
\end{tabular}

Source: Primary data

Based on Table 6. it was found that the majority (45\%) of respondents 'attitudes before getting health promotion were in the positive category and the majority (47\%) of respondents' attitudes after 
getting health promotions were in the positive category. Based on the test with Mc Nemar, the results showed that $\mathrm{p}=0.845$ means that there was no effect of health promotion on the attitude of respondents regarding anemia prevention.

Table 7.Application Pender's Health Promotion Model on Mother's Behavior of Anemia Prevention in Kubutambahan II Primary Health Care, 2019

\begin{tabular}{lcccc}
\hline Behavior & \multicolumn{2}{c}{ Pre } & \multicolumn{2}{c}{ Post } \\
& $\sum$ & $\% \sum$ & $\sum$ & $\% \sum$ \\
\hline Good & 50 & 50 & 70 & 70 \\
Less & 50 & 50 & 30 & 30 \\
Total & 100 & 100 & 100 & 100 \\
\hline Mc & & & & \\
Nemarp $=0,000$ & & & & \\
\hline Sorce Primary & & & &
\end{tabular}

Source: Primary data

Based on Table 7. it was found that most $(50 \%)$ of the behaviors before getting health promotion were in the good category and the majority $(70 \%)$ of the respondents' behavior after getting health promotion was in the good category. Based on the test with Mc Nemar, the result $p=0,000$ means that there is an effect of health promotion on the behavior of respondents regarding anemia prevention.

\section{DISCUSSION}

\section{Pender's Health Promotion Model On Mother's Knowledge}

The results showed that there was an influence between health promotion and mother's knowledge about preventing anemia in children. Provision of health promotion can increase knowledge / information about the prevention of maternal anemia in children. This is consistent with existing theories that knowledge is the result of knowing, which occurs after people have sensed a particular object (Notoatmodjo, 2003). Knowledge is also the result of remembering a thing, including recalling events that have been experienced either intentionally or unintentionally and this happens after people make contact or observation of a particular object (Mubarok and Wahid, 2007). The purpose of health promotion activities is to increase knowledge and attitudes about health so that it will facilitate the occurrence of healthy behavior (Notoatmodjo, 2003).

The results of this study are consistent with research in Pekalongan about the effect of interaction, knowledge and attitudes of mothers on the practice of preventing iron anemia in infants, which shows the influence of knowledge and practice of preventing iron anemia in infants. Research in Yogyakarta also found the same thing that there is an effect of anemia health education in adolescent girls on anemia prevention knowledge (Kusuma, 2014). Other research that also supports is research on the effect of health promotion on knowledge about cervical cancer which shows that there is an influence between health promotion with knowledge about cervical cancer (Saraswati, 2011).

\section{Pender's Health Promotion Model On Mother's Attitude}

The results showed that before health promotion was obtained some (45\%) of respondents had a positive attitude and as many as $(55 \%)$ had a negative attitude and after getting health promotion were obtained as many as $(47 \%)$ respondents had a positive attitude and a portion $(53 \%)$ of respondents had an attitude negative. Statistical test results with Mc Nemar obtained $p=0.845>0.05$ meaning that there is no influence between health promotion on maternal attitudes in preventing anemia. The results of this study are not in accordance with research in Surakarta about the effect of health education on the knowledge and attitudes of pregnant women in consuming Fe tablets (Ferum) which indicate that there is an influence of health education on mothers' attitudes in consuming Fe tablets (Astuti, 2012). 
Factors that influence attitudes are internal factors: physiological (sick, hungry, thirsty), psychological (interests and attention) and external motives and factors: experience, situation, norms, obstacles and driving forces (Maulana, 2007). The attitude of the mother before being given a health promotion found 45 respondents had a positive attitude and after being given a health promotion only found 47 respondents who had a positive attitude. This may be due to the cultural and cultural factors that already exist in each village in the Kubutambahan that they only provide foods that are preferred by children without regard to nutritional status and have no experience of children with anemia.

\section{Pender's Health Promotion Model On Mother's Behavior}

The results showed that before getting a health promotion it was found $(50 \%)$ of respondents had good behavior, and as many as $(50 \%)$ of respondents had less knowledge, after getting a health promotion it was found that most $(70 \%)$ respondents had good categories of behavior and a small portion $(30 \%)$ of respondents have sufficient behavior. Statistical test results with Mc Nemar found $\mathrm{p}$ $=0,000<0.05$ meaning that there is an influence between health promotion on maternal behavior.

This is in accordance with the theory of health promotion is a process to enable the community to maintain and improve health (Notoatmodjo, 2003). The purpose of health promotion activities is to increase knowledge and attitudes about health so that it will facilitate healthy behavior (Maulana, 2007). In this study despite the negative attitude of the respondents, the family always reminded about the benefits of anemia prevention and the types of food needed by children to prevent anemia. The role of community health workers also exemplifies the food that can be served to children to prevent anemia. Families and cadres are also involved by always reminding respondents to maintain a healthy life even though anemia has not yet occurred, motivating children to eat breakfast and want to consume vegetables and cook in the right way so that the child's nutrition is optimally fulfilled.

\section{CONCLUSION}

There is an effect of health promotion on mother's knowledge about anemia prevention $(p=0,000)$, there is an effect of health promotion on mother's behavior about anemia prevention $(p=0,000)$, there is no effect of health promotion on mother's attitudes about anemia prevention $(\mathrm{p}=0.845)$. Health promotion by conducting outreach to the community needs to be carried out continuously by involving all aspects ranging from health workers, community leaders, community health workers and families to improve community health status

\section{ACKNOWLEDGMENTS}

The author is thankful for respondents for their valuable information and its awareness to participate in this research

\section{CONFLICTS OF INTEREST}

The author declares that they have no conflict of interest.

\section{REFERENCES}

Astuti (2012). Pengaruh Pendidikan Kesehatan terhadap Perubahan Pengetahuan dan Sikap Ibu Hamil dalam Mengkonsumsi tablet Fe (Ferum) di Rumah Bersalin Sri Lumintu Surakarta, Fakultas Ilmu Kesehatan Universitas Muhammadiyah Surakarta. Retrieved from http://eprints.ums.ac.id/21913/

Health Department of RI (2007). Gizi Tentukan Kualitas, Depkes RI: Jakarta

Kisworini \& Mulatsih (2005). Penyebab Kejadian Anemia Pada Anak Usia Sekolah. Retrieved from http://www.gocitis.com/bbid.geo/artikel/66htm 
Kusuma (2014). Pengaruh Pendidikan Kesehatan Anemia pada Remaja Putri terhadap Tingkat Pengetahuan dan Sikap dalam Pencegahan Anemia pada Siswi Kelas X SMA Muhammadiyah Yogyakarta, Jurnal Stikes Aisyiyah Yogyakarta. Retrieved from http://digilib.unisayogya.ac.id/1132/

Maulana (2007). Promosi Kesehatan. EGC: Jakarta

Mubarok, Wahid (2007). Promosi Kesehatan Sebuah Pengantar Proses Belajar Mengajar dalam Pendidikan, Graha Ilmu: Yogyakarta

Notoatmodjo (2003). Pendidikan dan Perilaku Kesehatan. Rineka Cipta: Jakarta

Saraswati (2011). Pengaruh Promosi Kesehatan terhadap Pengetahuan tentang Kanker Serviks dan Partisipasi Wanita dalam Deteksi Dini Kanker Serviks, Tesis, Program Pasca Sarjana Universitas Sebelas Maret Surakarta

Pender di IGD RSUD Ruteng, Jurnal Pediomaternal, Vol.3 No.2, hal.230-248

Supartini (2004). Buku Ajar Konsep Dasar Keperawatan Anak. EGC: Jakarta

Syah, J. (2007). Status Anemia Balita Dayak Kanayan. Jurnal Penelitian. Pontianak: Politekkes Pontianak

WHO (2001). Iron Deficiency Anaemia: Assesment, Prevention and Control, WorldHealth Organization, Genewa

WHO (2008). World Wide Prevalence of Anemia, http://www.who.int 